\title{
Antibiotic Susceptibility Profile of Respiratory Pathogens Obtained at Tertiary Care Hospital from Western Nepal
}

Deepak Subedi ${ }^{1}$, Surya Prasad Devkota ${ }^{1,2,3 *}$, Dharm Raj Bhatta ${ }^{4}$, Binita Koirala Sharma ${ }^{1}$,

Ashmita Paudel ${ }^{2}$, Krishna Gurung ${ }^{1,5}$, Damodar Gautam ${ }^{1}$

${ }_{1}^{1}$ Pokhara Bigyan Tatha Prabidhi Campus, Nayabazar, Pokhara

2Regional College of Health Science and Technology, Nayabazar, Pokhara

${ }^{3}$ School of Health and Allied Sciences, Pokhara University, Pokhara

${ }^{4}$ Manipal College of Medical Sciences, Pokhara

${ }_{5}^{5}$ Prithvi Narayan Campus, Pokhara

\begin{abstract}
The prevalence and drug resistance of the respiratory pathogens is increasing gradually in Nepal. However, their detail study is rare in the western region of Nepal. Hence, this study was carried out to know the incidence and antibiotic susceptibility profile of the respiratory pathogens obtained at a tertiary care center located at Pokhara. 139 pathogens were isolated from 460 clinical samples included. Significant pathogens were Gram-negative bacteria 94 (67.62\%), followed by $28(20.15 \%)$ Candida, and Gram-positive isolates $17(12.23 \%)$. The growth rate was significantly higher for sputum samples in comparison to throat swabs. Pseudomonas aeruginosa, Klebsiella pneumoniae, and Acinetobacter spp were significant Gram-negative isolates while Staphylococcus aureus, Streptococcus pneumoniae, and Streptococcus pyogenes were Grampositive pathogens. Sensitivity rate was higher for colistin and imipenem among Gram-negative isolates while lower sensitivity was for cefepime. Vancomycin was effective against all tested Gram-positive isolates while erythromycin and ciprofloxacin were less effective.

Keywords: respiratory pathogens, western Nepal, Pseudomonas aeruginosa, Acinetobacter spp, Klebsiella pneumonia, S. aureus.
\end{abstract}

*Corresponding Author

Email: devkotasp1@gmail.com

\section{Introduction}

Infection of the respiratory tract is a significant cause of mortality as well as morbidity among the elderly and young people of Nepal [1]. Management of these infections is more complex in developing countries due to the lack of the proper identification of pathogens and their suitable treatment [2]. The causative agents of the respiratory infections are not detected in many cases hence physicians depend on clinical manifestations for the diagnosis [3]. Klebsiella pneumaniae, Streptococcus pneumoniae, and Haemophilus influenzae are the significant pathogens causing respiratory infections $[4,5]$. In addition to this, pathogens like Staphylococcus aureus, Acinetobacter, and Pseudomonas aeruginosa are also frequently isolated from respiratory specimens $[6,7]$.

Polymicrobial respiratory infections by two or more bacteria, two or more viral pathogens, and mixed viral and bacterial pathogens also have been reported $[4,5]$. Pneumonia and infection of lower respiratory tract are the causes of more than 4 million deaths per year and this problem is more frequent in middle-and low-income nations [8]. Drug resistance among these pathogens has been increasing as there are multiple reports of multidrug resistance among various respiratory pathogens and many of them are not susceptible to several routine antibiotics $[4,9]$. Though most of the bacterial respiratory infections are treatable, the huge death is due to a lack of proper preventive measures and unavailability of healthcare facilities [8]. Several reports are indicating a gradual increase in antibiotic resistance among many bacterial pathogens responsible for respiratory diseases $[10,11]$.

The imprudent use of antibiotics for treating these infections has resulted in a very rapid increase in drug resistance of the respiratory pathogens [12]. Though various pathogens [13] and risk factors [14] are associated with 


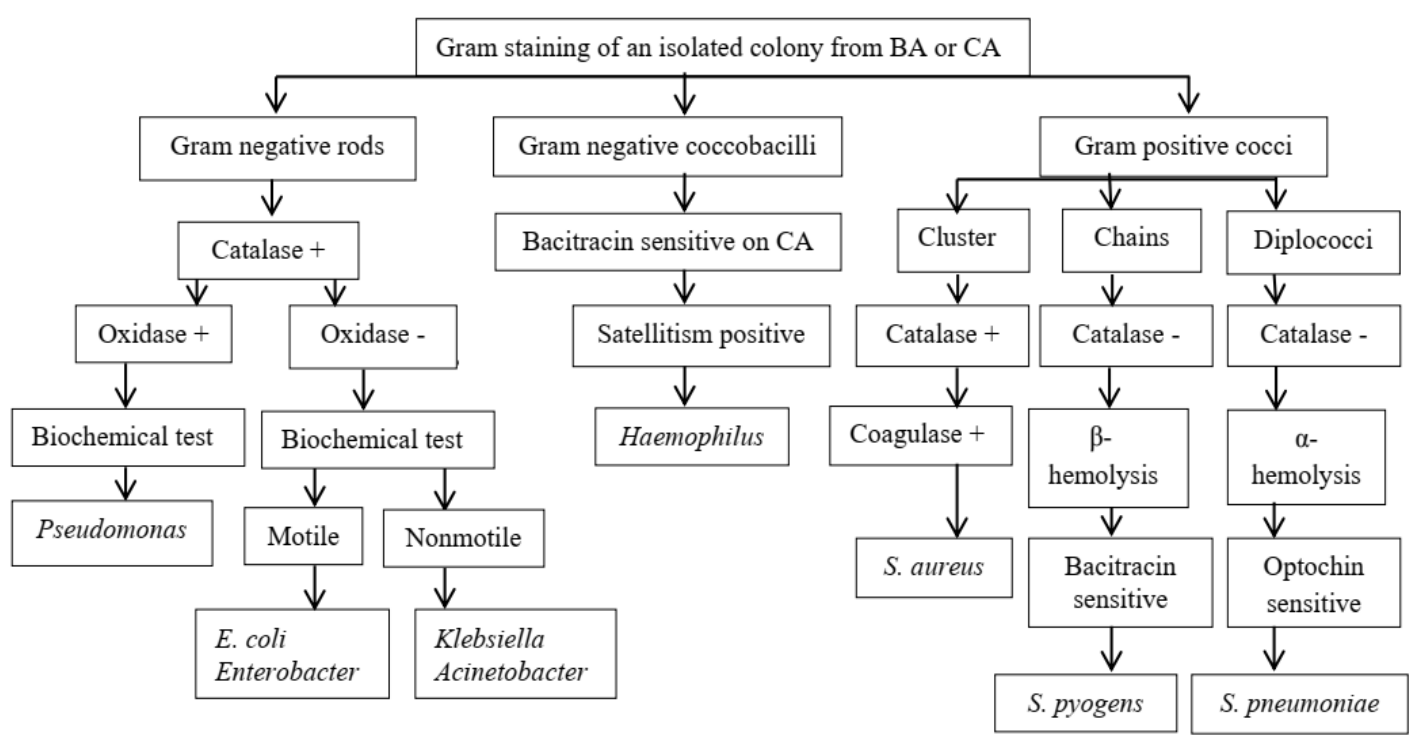

Figure 1: Identification chart for the pathogens isolated from respiratory samples.

respiratory infections, their detail study is very limited in this region. Surveillance study on respiratory pathogens was imminent in this part of the nation. Hence this study was done to access the prevalence, distribution and drug resistance profile of the respiratory pathogens isolated at a tertiary care center of western Nepal.

\section{Materials and Methods Study site and duration}

The study site was Manipal Teaching Hospital, a 750-bed multi-specialty tertiary care hospital located at Pokhara, Nepal. The study was conducted for a period of six months (July 2016 to January 2017) at the Microbiology laboratory of the hospital.

\section{Sample collection}

Samples were collected from patients with clinical symptoms of respiratory tract infection as indicated by physicians. For the collection of sputum samples, patients were given various instructions on how to collect a sputum sample correctly. Clean, well-labeled, wide-necked, dry and leak-proof screw-cap container was provided to the patients for sputum collection. The sample was accepted only if it was sputum but samples containing saliva, nasal secretions, mucus, etc. were not analyzed. In the case of unacceptable samples, repeated samples were requested. Throat sample was collected by trained personals. The patient was first allowed to sit comfortably in a good light and using a tongue depressor the throat was observed for any swelling, redness, pus, ulcerations, exudates, and presence of the membrane. A sterile cotton swab was used to collect a sample of the infected throat. Special care was taken not to contaminate the swab with saliva and placed it into a sterile container.

\section{Macroscopic and microscopic examination of the sample}

Appearance, as well as presence or absence of blood in the given sputum, was observed and noted. Similarly, gram staining was performed from both sputum and throat swabs to observe pus cells and bacteria.

\section{Isolation and identification}

Respiratory tract samples obtained from both admitted and outpatients visiting the hospital were included in this study. Soon after collection, all the specimens were cultured on chocolate agar and 5\% sheep blood agar. The inoculated plates were then incubated on candle jar for 18-24 hours. Optochin and bacitracin discs were placed on the primary inoculation for the presumptive screening of $S$. pneumoniae and $H$. influenzae as well as $S$. pyogens respectively. Identification of the pure culture was carried out by observing colony characteristics and gram staining followed by oxidase test, catalase test, coagulase test, urease test, TSI test, and IMViC tests. 


\section{Antibiotic susceptibility test}

Kirby-Bauer disc diffusion method was used using Muller Hinton agar (Hi-Media, India). Clinical and Laboratory Standards Institute (CLSI) guidelines were used for the interpretation of the results [15]. 0.5 Mac Farland suspension of the isolates were used for inoculation. Amikacin $(30 \mu \mathrm{g})$, Azithromycin $(15 \mu \mathrm{g})$, Cefepime $(30 \mu \mathrm{g})$, Ceftriaxone $(30 \mu \mathrm{g})$,

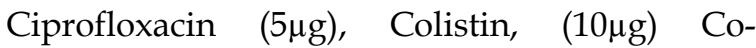

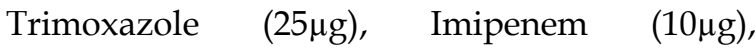
Piperacillin/ Tazobactam (100 $\mu \mathrm{g} / 10)$,

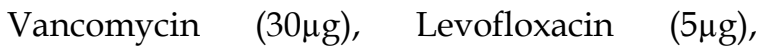

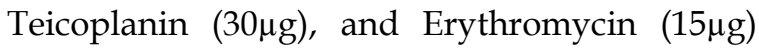
were used for the test. E. coli ATCC 25922 was used as a control organism for Gram-negative isolates while Staphylococcus aureus ATCC 25923 was used as a control organism for Gram-positive isolates during this test.

\section{Results}

Among 460 samples, 139 (30.2\%) showed the growth of respiratory pathogens. The incidence of the pathogens was higher from the sputum sample in relation to the throat sample (Table 1). Pseudomonas aeruginosa, Acinetobacter spp., Klebsiella pneumoniae, Staphylococcus aureus, Escherichia coli, and Candida spp. were the common pathogens isolated followed by Haemophilus influenzae, Streptococcus pneumoniae, Streptococcus pyogenes, and Enterobacter spp. Streptococcus pyogenes were isolated only from throat swab while all gram-negative isolates were only from the sputum sample. Only Candida was isolated from both of the samples (Table 2).

Table 1: Total cases and types of samples

\begin{tabular}{lccc}
\hline Samples & $\begin{array}{c}\text { Growth } \\
\text { positive (\%) }\end{array}$ & $\begin{array}{c}\text { Growth } \\
\text { negative (\%) }\end{array}$ & Total (\%) \\
\hline Sputum & $134(29.13 \%)$ & $299(65 \%)$ & $433(94.13 \%)$ \\
$\begin{array}{l}\text { Throat } \\
\text { swab }\end{array}$ & $5(1.07 \%)$ & $22(4.8 \%)$ & $27(5.87 \%)$ \\
\hline Total & $139(30.2 \%)$ & $321(69.8 \%)$ & $460(100 \%)$ \\
\hline
\end{tabular}

Vancomycin was the most effective drug for all three Gram-positive pathogens as all of these isolates were sensitive to vancomycin. Teicoplanin and clindamycin were also highly
Table 2: Distribution of Gram-positive cocci, Gramnegative bacilli and Candida spp. in throat swab and sputum samples

\begin{tabular}{|c|c|c|c|}
\hline \multirow[b]{2}{*}{ Microorganisms } & \multicolumn{2}{|c|}{ Samples } & \multirow[b]{2}{*}{ Total $(\%)$} \\
\hline & $\begin{array}{c}\text { Throat } \\
\text { swab } \\
(\%)\end{array}$ & $\begin{array}{l}\text { Sputum } \\
\qquad \%)\end{array}$ & \\
\hline $\begin{array}{l}\text { Pseudomonas } \\
\text { aeruginosa }\end{array}$ & 0 & $31(22.3)$ & $31(22.3)$ \\
\hline Acinetobacter spp & 0 & $26(18.7)$ & $26(18.7)$ \\
\hline $\begin{array}{l}\text { Klebsiella } \\
\text { pneumoniae }\end{array}$ & 0 & $23(16.55)$ & $23(16.55)$ \\
\hline $\begin{array}{l}\text { Staphylococcus } \\
\text { aureus }\end{array}$ & 0 & $9(6.47)$ & $9(6.47)$ \\
\hline Escherichia coli & 0 & $8(5.76)$ & $8(5.76)$ \\
\hline $\begin{array}{l}\text { Haemophilus } \\
\text { influenza }\end{array}$ & 0 & $4(2.88)$ & $4(2.88)$ \\
\hline $\begin{array}{l}\text { Streptococcus } \\
\text { pneumoniae }\end{array}$ & 0 & $4(2.88)$ & $4(2.88)$ \\
\hline $\begin{array}{l}\text { Streptococcus } \\
\text { pyogenes }\end{array}$ & $4(2.88)$ & 0 & $4(2.88)$ \\
\hline Enterobacter spp & 0 & $2(1.44)$ & $2(1.44)$ \\
\hline Candida spp. & $1(0.72)$ & 27 (19.42) & $28(20.14)$ \\
\hline Total & $5(3.6)$ & $134(96.4)$ & $139(100)$ \\
\hline
\end{tabular}

active against $S$. aureus and Streptococcus pyogenes respectively while other drugs were less effective as there was resistance ranging from 22 to $100 \%$ for antibiotics other than vancomycin, teicoplanin, and clindamycin (Table 3 ). Colistin was the most effective drug for treating Pseudomonas aeruginosa and Acinetobacter. Least drug resistance was noted on Enterobacter while the highest resistance was observed on Acinetobacter. Resistance towards all common antibiotics was observed in all Gram-negative pathogens excluding Enterobacter with varying percentages (Table 4 ).

\section{Discussion}

Nearly one-third of the samples were positive for the respiratory pathogens. Findings of the Shrestha et al (2005) also reported that $31 \%$ of the sputum samples were positive for pathogens [16]. Among the isolated pathogens Gramnegative isolates were more prevalent than Gram-positive pathogens. 
Table 3: Antimicrobial susceptibility profiles of Gram-positive isolates

\begin{tabular}{|c|c|c|c|c|c|c|}
\hline \multirow{3}{*}{$\begin{array}{l}\text { Antibiotics } \\
\text { used }\end{array}$} & \multicolumn{6}{|c|}{ Pathogens } \\
\hline & \multicolumn{2}{|c|}{$\begin{array}{l}\text { Staphylococcus aureus } \\
\qquad(\mathrm{n}=9)\end{array}$} & \multicolumn{2}{|c|}{$\begin{array}{l}\text { Streptococcus pyogenes } \\
\qquad(\mathrm{n}=4)\end{array}$} & \multicolumn{2}{|c|}{$\begin{array}{l}\text { Streptococcus pneumoniae } \\
\qquad(\mathrm{n}=4)\end{array}$} \\
\hline & $\begin{array}{l}\text { Sensitive } \\
\text { No. }(\%)\end{array}$ & $\begin{array}{l}\text { Resistant } \\
\text { No. }(\%)\end{array}$ & $\begin{array}{l}\text { Sensitive } \\
\text { No. }(\%)\end{array}$ & $\begin{array}{l}\text { Resistant } \\
\text { No. }(\%)\end{array}$ & $\begin{array}{l}\text { Sensitive No. } \\
\qquad(\%)\end{array}$ & $\begin{array}{c}\text { Resistant } \\
\text { No. (\%) }\end{array}$ \\
\hline Amikacin & $7(77.8)$ & $2(22.2)$ & $3(75)$ & $1(25)$ & - & - \\
\hline Ciprofloxacin & $3(33.3)$ & $6(66.7)$ & - & - & - & - \\
\hline Clindamycin & $2(22.2)$ & $7(77.8)$ & $4(100)$ & 0 & $2(50)$ & $2(50)$ \\
\hline Co-Trimoxazole & - & - & - & - & $1(25)$ & $3(75)$ \\
\hline Erythromycin & $2(22.2)$ & $7(77.8)$ & 0 & $4(100)$ & $2(50)$ & $2(50)$ \\
\hline Levofloxacin & - & - & 0 & $4(100)$ & $3(75)$ & $1(25)$ \\
\hline Teicoplanin & $9(100)$ & 0 & - & - & - & - \\
\hline Vancomycin & $9(100)$ & 0 & $4(100)$ & 0 & $4(100)$ & 0 \\
\hline
\end{tabular}

Table 4: Antimicrobial susceptibility profiles of Gram-negative bacilli

\begin{tabular}{|c|c|c|c|c|c|c|}
\hline \multirow{3}{*}{$\begin{array}{l}\text { Antibiotics } \\
\text { Used }\end{array}$} & \multicolumn{6}{|c|}{ Pathogens } \\
\hline & $\begin{array}{l}\text { Pseudomonas } \\
\text { aeruginosa } \\
\quad(\mathrm{n}=31)\end{array}$ & $\begin{array}{c}\text { Acinetobacter } \\
\text { spp } \\
(\mathrm{n}=26)\end{array}$ & $\begin{array}{c}\text { Klebsiella } \\
\text { pneumoniae } \\
(\mathrm{n}=23)\end{array}$ & $\begin{array}{l}\text { E. coli } \\
(\mathrm{n}=8)\end{array}$ & $\begin{array}{l}\text { Haemophilus } \\
\text { influenzae } \\
(\mathrm{n}=4)\end{array}$ & $\begin{array}{c}\text { Enteroba } \\
\text { cter } \\
\text { spp } \\
(\mathrm{n}=2)\end{array}$ \\
\hline & S (\%) & S (\%) & S (\%) & $\mathrm{S}(\%)$ & S (\%) & S (\%) \\
\hline Amikacin & $26(83.9)$ & $8(30.8)$ & $15(65.2)$ & $8(100)$ & - & $2(100)$ \\
\hline Azithromycin & - & - & - & - & $2(50)$ & - \\
\hline Cefepime & $7(22.6)$ & $6(23.1)$ & $6(26.1)$ & 0 & - & $2(100)$ \\
\hline Ceftriaxone & - & - & - & - & $3(75)$ & - \\
\hline Ciprofloxacin & $22(71)$ & $8(30.8)$ & $10(43.5)$ & $2(25)$ & $4(100)$ & $2(100)$ \\
\hline Colistin & 31 (100) & $26(100)$ & - & - & - & - \\
\hline Co-Trimoxazole & - & - & $8(34.8)$ & $5(62.5)$ & $2(50)$ & $2(100)$ \\
\hline Imipenem & $23(74.2)$ & $9(34.6)$ & $21(91.3)$ & $7(87.5)$ & - & $2(100)$ \\
\hline $\begin{array}{l}\text { Piperacillin/ } \\
\text { Tazobactam }\end{array}$ & $13(42)$ & $5(19.2)$ & $7(30.4)$ & $3(37.5)$ & - & $2(100)$ \\
\hline
\end{tabular}

A very high incidence of Gram-negative pathogens among respiratory samples are also reported earlier [2, 12, 16]. Gram-negative isolates like Pseudomonas aeruginosa, Acinetobacter spp., Klebsiella pneumoniae were predominant. These findings were in accordance with the previous studies $[13,17]$. Similarly, Staphylococcus aureus was the major Gram-positive pathogens.
Pathogens like Streptococcus pneumoniae, Streptococcus pyogenes were also isolated from the respiratory samples. The predominance of Staphylococcus aureus among Gram-positive pathogens followed by Streptococcus spp. is common from respiratory samples [1, 3, 18]. Candida isolates were also the major cause of 
respiratory infections as indicated by previous authors $[3,19]$.

Vancomycin was the most reliable treatment option for all of the gram-positive pathogens isolated. The high sensitivity of vancomycin against S. aureus and Streptococcus spp isolated from respiratory tract infection is found elsewhere $[18,19,20]$. More than $66 \%$ of S. aureus were resistant to Ciprofloxacin, Clindamycin, and Erythromycin. Increasing resistance of $S$. aureus towards these drugs is common globally $[18,20]$. All Streptococcus pyogenes isolated in this study were sensitive to Clindamycin and Vancomycin while they were absolutely resistant to Levofloxacin and Erythromycin. Very similar antibiotic sensitivity patterns of Streptococcus pyogenes are reported earlier [21,22]. The majority of Streptococcus pneumoniae were resistant against Co-Trimoxazole, Clindamycin, and Erythromycin. An elevated level of resistance among Streptococcus pneumoniae obtained from sputum and other samples are reported from different countries [23].

Colistin resistance was not observed in Pseudomonas aeruginosa and Acinetobacter spp. indicating that this drug is still effective as a last resort. There are many reports of absolute colistin sensitivity among gram-negative respiratory pathogens [24, 25]. However, there is a report of colistin resistance among multidrug-resistant Acinetobacter spp isolates obtained from ICU patients suffering from respiratory tract infection in Nepal [26]. Imipenem and amikacin resistance was less in gram-negative isolates in comparison to other antibiotics like Cefepime, Ciprofloxacin, Piperacillin/ Tazobactam. Less resistance is detected in common respiratory gram-negative pathogens against Imipenem and amikacin [24, 27]. Drug resistance was higher in Acinetobacter spp among Gram-negative pathogens. Highly elevated antibiotic resistance among Acinetobacter isolated from respiratory tract infection is reported previously in Nepal $[17,26]$. We also noticed drug resistance among Haemophilus influenzae as some isolates were not sensitive to Azithromycin, Ceftriaxone, and Co-Trimoxazole. Antibiotic-resistant Haemophilus influenzae causing respiratory tract infection is not new [2].

\section{Conclusion}

Pseudomonas aeruginosa, Acinetobacter spp., Klebsiella pneumoniae, Candida, and S. aureus were the major isolates causing respiratory infection. Many of these isolates were resistant to various routine drugs. To prevent the further increase of antimicrobial resistance among the respiratory isolates antibiotic susceptibility testing must be done before therapy.

\section{Author Contributions}

DS and SPD designed the research proposal, DS performed the lab works, DRB, BKS, and KG supervised the work, AP, SPD and DG wrote the article. All the authors read, revised, and finalized the manuscript.

\section{Acknowledgment}

The authors are thankful to all the members of the Microbiology laboratory of Manipal Teaching Hospital for their continuous support during this work as well as to the patients for providing samples for this research.

\section{References}

1. Shrestha S, Acharya A, Gautam A, Nepal H, Gautam R, Ansari $S$, et al: Lower respiratory tract pathogens and their antimicrobial susceptibility pattern in a medical hospital of central Nepal. Int J BiomedAdv Res. 2013 4(5): 335-340. [https://www.researchgate.net/ publication/272566188]

2. Khan S, Priti S, Ankit S: Bacteria Etiological Agents Causing Lower Respiratory Tract Infections and Their Resistance Patterns. Iran biomed J. 2015 19(4): 240-46.[https:/ / www.ncbi. nlm.nih.gov/pmc/articles/PMC4649860/]

3. Ahmed SMA, Abdelrahman SS, Saad DM, Osman IS, Osman MG, Khalil EAG: Etiological trends and patterns of antimicrobial resistance in respiratory infections. Open Microbiol J. 2018 12: 34-40. [https://www.ncbi. nlm.nih.gov/pmc/articles/PMC5897982/]

4. Bhuyan GS, Hossain MA, Sarker SK, Rahat A, Islam MT, Haque TN, et al: Bacterial and viral pathogen spectra of acute respiratory infections in under-5 children in hospital settings in Dhaka city. PLoS ONE. 201712 (3): 448-454. [https://journals.plos.org/plosone / article?id=10.1371/journal. pone.0174488]

5. Chen J, Li X, Wang W, Jia Y, Lin F, Xu J: The prevalence of respiratory pathogens in adults with community-acquired pneumonia in an outpatient cohort. Inf Drug Resist. 2019 12:23352341. [https://www.ncbi.nlm.nih.gov/ pmc/articles/PMC6679678/]

6. Chung DR, Song JH, Kim SH, Thamlikitkul V, Huang SG, Wang $\mathrm{H}$, et al: High prevalence of 
multidrug-resistant nonfermenters in hospital-acquired pneumonia in Asia. Am J Respir Crit Care Med. 2011 184:1409-17. [https://www.ncbi.nlm.nih.gov/pubmed/219 20919]

7. Liu F, Wen Z, Wei J, Xue H, Chen Y, Gao W, et al: Epidemiology, microbiology and treatment implications in adult patients hospitalized with pneumonia in different regions of China a retrospective study. J thorac dis. 2017 9(10): 3875-87. [https://www.ncbi.nlm.nih.gov/ pmc/articles/PMC5723798/]

8. Forum of International Respiratory Societies. The Global Impact of Respiratory Disease Second Edition. Sheffield, European Respiratory Society, 2017. [https://www.who.int/gard/publications/Th e_Global_Impact_of_Respiratory_Disease.pdf]

9. Odrigo-Troyano A, Sibila $O$. The respiratory threat posed by multidrug resistant Gramnegative bacteria. Respirology. 2017 22:12881299. [onlinelibrary.wiley.com/doi/full/10. 1111 /resp.13115]

10. Karchmer AW: Increased Antibiotic Resistance in Respiratory Tract Pathogens: PROTEKT USAn Update. Clin Infect Dis. 200439 (3): S142-50. [https://academic.oup.com/cid/article/39/Su pplement_3/S142/288433]

11. Xia W, Chen Y, Mei Y, Wang T, Liu G, Gu B et al.: Changing trend of antimicrobial resistance among pathogens isolated from lower respiratory tract at a university-affiliated hospital of China, 2006-2010. J Thorac Dis. 2012 4: 284-291. [https://www.ncbi.nlm.nih.gov/ pmc/articles/PMC3378186/]

12. Thomas AM, Jayaprakash C, Amma GMR: The pattern of bacterial pathogens and their antibiotic susceptibility profile from lower respiratory tract specimens in a rural tertiary care centre. J Evolution Med Dent Sci. 2016 5(40): 2470-2476. [https://www.jemds.com/data_pdf /2_Chitra.pdf]

13. Mishra SK, Kattel HP, Acharya J, Shah NP, Shah AS, Sherchand JB et al: Recent trend of bacterial aetiology of lower respiratory tract infections in a tertiary care centre of Nepal. Int J Infect Microbiol. 2012 1(1): 3-8. [https://doi.org /10.3126/ijim.v1i1.6639]

14. Pant S, Bhusal KR, Manandhar S: Microbiology of lower respiratory tract infection in workers of garment industry of Kathmandu. JCMS-Nepal. 2014 10(3): 14-22. [https:// doi.org/10.3126/jcmsn.v10i3.12772]

15. Clinical and Laboratory Standards Institute: Performance standards for antimicrobial susceptibility testing, twenty-second informational supplement, CLSI, Document M100 S27, CLSI, Wayne, Pa, USA, 2017.

16. Shrestha U, Singh A, Pokhrel B: Cross-sectional study of respiratory pathogens and their antibiotic susceptibility pattern in Tribhuvan University Teaching Hospital. JIOM. 2006 28(2):59. [https://www.nepjol.info/index.php /JIOM/article/view/590]
17. Nepal R, Shrestha B, Joshi DM, Joshi RD, Shrestha S, Singh A: Antibiotic Susceptibility Pattern of Gram-negative Isolates of Lower Respiratory Tract Infection. J Nepal Health Res Counc. 2018 16(1): 22-26. [http://jnhrc.com.np/index.php/jnhrc/article /view/1117/671]

18. Bajpai T, Shrivastava G, Bhatambare GS, Deshmukh AB, Chitnis V: Microbiological profile of lower respiratory tract infections in neurological intensive care unit of a tertiary care center from Central India. J Basic Clin Pharm. 2013 4(3):51-55. [https://www.ncbi. nlm.nih.gov/pmc/articles/PMC3979271/]

19. Kumar SV, Kumar GPV, Kandati J, Pathapati RM, Buchineni M: A Surveillance Study of Microbial Pathogens and their Antibiotic Sensitivity of Respiratory Tract Infections in a Tertiary Care Hospital. Int J Curr Microbiol App Sci. 2015; 4(11):35-44. [https://www.ijcmas. com/vol-4-11/S.Vijaya\%20Kumar,\%20et \%20al.pdf]

20. Anvari MS, Naderan M, Boroumand MA, Shoar S, Bakhshi R, Naderan M: Microbiologic spectrum and antibiotic susceptibility pattern among patients with urinary and respiratory tract infection. Int J Microbiol. 2014 2014: 682304. [https://www.hindawi.com/journals/ijmicro /2014/682304/]

21. Camara M, Dieng A, boye CSB: Antibiotic susceptibility of Streptococcus Pyogenes isolated from respiratory tract infections in Dakar, Senegal. Microbiol. Insights. 2013 6: 7175.[https:// www.ncbi.nlm.nih.gov/pmc/articl es/PMC3987753/]

22. Dhanda V, Chaudhary P, Toor D, Kumar R, Chakraborti A: Antimicrobial susceptibility pattern of B-haemolytic group A, C and G streptococci isolated from North India. J Med Microbiol. 2013 62: 386-93.[https://jmm. microbiologyresearch.org/content/journal/jm m/10.1099/jmm.0.046672-0\#tab2]

23. Kim L, McGee L, Tomczyk S, Beall B: Biological and Epidemiological Features of AntibioticResistant Streptococcus pneumoniae in Preand Post-Conjugate Vaccine Eras: a United States Perspective. Clin Microbiol Rev. 2016 29(3):525-52.[https://www.ncbi.nlm.nih.gov/ pmc/articles/PMC4861989/]

24. Thomas SS, Sreenath K, Sebastian S: Characterization of the antibiotic profile of Pseudomonas aeruginosa isolates from a tertiary care center. Int J Res Med Sci. 2016 4: 5714. [https://www.msjonline.org /index.php /ijrms/article/view/542]

25. Guzek A, Rybicki Z, Korziniewski K, Mackiewicz K, Saks E, Chcialowski A: Aetiological factor causing lower respiratory tract infections isolated from hospitalized patients. Adv Exp med Biol. 2015 835: 37-44. [https://link.springer.com/chapter/10.1007\%2 F5584_2014_23]

26. Bhatta DR, Hamal D, Shrestha R, Supram HS, Joshi P, Nayak N, et al: Burden of multidrug 
resistant respiratory pathogens in intensive care units of tertiary care hospital. Asian J Med Sci. 2019 10(2):14-19. [https://www.nepjol. info/index.php/AJMS/article/view/21098]

27. Regha R, Sulekha B: Bacteriological profile and antibiotic susceptibility patterns of lower respiratory tract infections in a tertiary care hospital, Central Kerala. Int J Med Microbiol Trop Dis. 2018 4(4): $186-90$. [http://snims.org/files/Microbiology/2.pdf] 